\title{
Creative artistic and musical activity of the child as a process of socialization
}

\author{
Irina Vladimirovna Wagner1* \\ Ekaterina Mikhaylovna Akishina** \\ Elena Petrovna Olesina*** \\ ${ }^{*}$ Corresponding author, Institute of Art Education and Cultural Studies of the Russian Academy \\ of Education, 8/1 Pogodinskaya str., Moscow, 119121, Russia. ORCID ID: 0000-0003-3932-1736, \\ e-Mail: Wagner.I.V@yandex.ru \\ **Institute of Art Education and Cultural Studies of the Russian Academy of Education, 8/1 \\ Pogodinskaya str., Moscow, 119121, Russia. ORCID ID: 0000-0002-1345-5202, e-Mmail: \\ ekaterina.m.akishina@mail.ru \\ ***Institute of Art Education and Cultural Studies of the Russian Academy of Education, \\ 8/1 Pogodinskaya str., Moscow, 119121, Russia. ORCID ID: 0000-0002-3703-0356. e-Mmail: \\ olesina611076@mail.ru
}

DOI 10.12975/rastmd.2021937 Submitted October 8, 2021 Accepted December 27, 2021

\begin{abstract}
The article presents key results of the research project "Socialization of children in difficult life situations by means of art" under the State Assignment of the Ministry of Education of the Russian Federation to the Institute of Art Education and Cultural Studies of the Russian Academy of Education for the year 2020. As a result of the conducted study based on the analysis of theoretical aspects of philosophical, psychological, sociological, pedagogical, and culturological conceptions concerning personality development through art, promising approaches to the creation of psychological and pedagogical conditions for the productive socialization of children in difficult situations are identified. The Concept of pedagogical support for the productive socialization of children in difficult situations by means of art is developed and includes a theoretical model for the organization of children's socialization and their integration into the sociocultural space through active artistic and creative activity. The potential of art and artistic activity in the socialization of children in difficult life situations is substantiated in the general cultural, social, and pedagogical aspects. The relationships between emotional and value self-identification of a person and their involvement in independent or collective artistic and creative activity are revealed.
\end{abstract}

\section{Keywords}

art education, children in difficult life situations, the potential of art, socialization.

\section{Introduction}

The prospects of socio-economic development of Russia in the context of new challenges of the global society are determined by the quality of human resources that form in the process of socialization of the younger generations. The priority of state policy in the field of childhood is reflected in the Decree of the President of the 
Russian Federation of May 29, 2017, No. 240, under which the Decade of Childhood was declared in Russia from 2018 to 2027. Today there are more than 29 million children in Russia including a large number of children in difficult life situations - orphans, children left without parental care, children from large and low-income families. There currently are over 700,000 orphans and children left without parental care and over 670,000 children with disabilities (Aleksandrova et al., 2021).

The creation of socio-pedagogical conditions for positive socialization of children in difficult life situations requires a great scientific and practical focus due to the fact that both social and psychological and pedagogical support for such categories of children in difficult life situations as migrant children, orphans, children left without parental care, and children with disabilities involves designing adaptive socialization models and targeted measures accounting for the specifics of each said category of children in difficult life situations, has to include ensuring optimal conditions for a child's life, learning, and development, adaptation of a child in various institutions, both social and educational, accompaniment and support for their entry into a new society, maintaining adequate selfesteem and confidence in relationships with peers and adults, finding their place in society, and satisfaction with their position in life (Shatskaya, 2021; Bogush et al., 2020). Solving the set of aforementioned problems calls for interdisciplinary research in the sphere of social and psychological and pedagogical support for children in difficult life situations, their families, and teachers working with such children in social and educational institutions. The study "Socialization of children in difficult life situations by means of art" conducted under the State Assignment of the Ministry of Education of the Russian Federation to the Institute of Art Education and Cultural Studies of the Russian Academy of Education for 2020, the results of which are presented in this article, emphasizes the potential of art, art education, and artistic and creative activities in providing positive socialization of children in difficult life situations.

\section{Literature review}

"Sociocultural environment is a totality of cultural values, generally accepted norms, laws, rules, scientific data, and technologies ("know-how") available to society and an individual in society for effective actions and interactions with all components of its living environment, primarily natural, technogenic, informational and social." (Ionin, 2004, p. 115).

The socio-cultural environment contributes to the formation of a holistic worldview in an individual, determines their spiritual and moral reference points, provides and contributes to their assimilation of various models and programs of behavior in different life situations including the difficult ones. Therefore, the study of the influence of the socio-cultural environment on a person and through a person on the whole society and the socially significant processes within it is an important direction in the culturology of education (Krylova, 2007) and educational culturology (Kudriavtsev (1999)). 
Around the end of the 19th and beginning of the 20th century, J. Dewey (1915) proposed to consider the social environment as the basis and the most important condition for the design, functioning, and development of any educational system. According to J. Dewey (1915), an educational organization should create a comfortable environment for a child in which their natural life would go, which, in turn, would be a prerequisite for maximizing the approximation of educational situations to reality, and this would ensure the personal acceptance of said situations by the child and promote teaching the child to communicate and act (including interaction) in situations as similar to reality as possible.

\section{L.S. Vygotsky (1983, p. 207) also} considered the educational environment as a social phenomenon “... because even when it (environment) acts as the natural environment, defining social aspects are nevertheless always present in its relation to a person. A person always uses social experience in relation to it". Modern American followers of the cultural-historical theory of L.S. Vygotsky (J. Wertsch, M. Cole, R. Shweder, etc.) disclose the concept of "sociocultural environment" from the point of unification of human intellectual development with the surrounding world including culture, society, and the historical time. J. Wertsch notes that the socio-cultural approach to intellectual development is founded on the assumption that any action is mediated, therefore, it cannot be separated from the context of the specific situation (environment) in which it occurred.
V.P. Zinchenko noticed that sociocultural context has a decisive influence on mastering the simplest tools and objects in preschool and preschool childhood. From very early on, it is revealed in gestures, facial expressions. At a later age, the socio-cultural context influences the processes of forming the image of the world, the nature of sensory standards, units of perception, memory patterns... up to the general style of behavior and activity. Teaching programs should be saturated with cultural traditions and historical contexts and parallels, with what L.S. Vygotsky called the socio-cultural context of development (Zinchenko, 2010; Zinchenko \& Morgunov, 1994).

Consequently, the issue of the need for scientific modeling of educational content that reveals a holistic image of culture in the given historically given context through universal forms of spirituality and cognition based on an individual's artistic and aesthetic mastery of the real world (Kudriavtsev, 1999) becomes relevant. The understanding of the essence, specificity, and structure of the socio-cultural educational environment allows us to substantiate the model of modern environment organization aimed at supporting the positive socialization of children in difficult life situations.

\section{L.S. Vygotsky's idea about the mutual} influence of natural and cultural factors in the process of child development is important for understanding the structure of the educational environment:

"The process of a normal child growing into civilization is usually a single alloy with processes of their organic maturation. Both planes of 
development - natural and cultural coincide and merge with each other. Both series of changes interpenetrate one another and essentially form a single direction of socio-biological formation of personality." (Vygotsky, 1983, p. 175).

This allows us to identify the social component that determines the nature of relationships in the educational environment.

V.I. Slobodchikov proposed an anthropological-psychological model of the educational environment. "The educational environment is the sociocultural forms of subject matter that are or may be included in the content of education" (Slobodchikov, 2005, p. 23). The richness and structuredness of educational resources are the main properties of the educational environment. In this case, educational resources are understood as the transformation of certain socio-cultural content into the content and means of education, the basis of the educational environment.

The model of the socio-cultural educational environment developed by V.V. Kozhevnikova and I.A. Lykova includes the following components: a child (a subject of educational relations; significant adults (parents and teachers); sociocultural experience (the target of educational); the subject-space component; culturally appropriate ways of different activities; additional resources; the sociocultural context of development; a system of subjects' interaction in the educational environment (communication vectors are marked with arrows). These components are necessary and sufficient for modeling a productive sociocultural educational environment based on didactic principles: amplification, initiation of subjectivity, anthropocentrism, multilevel integration, variability, the relationship of flexible individualization and productive socialization, naturalness, cultural appropriateness, etc. This model contributes to teachers' and parents' understanding of the fact that it is not the external aspect but the internal content of a child's sociocultural experience, cultural and personal meanings that are important in the structure of the activity experience of a child in a difficult life situation.

According to L.S. Vygotsky (1983), it is the creation or transformation of a material object (material, substance, subject, tool) reflecting all "passions" of activity (mutual relations between people) and "clots" of culture (extracted meanings) embodied in the amplifier of development that is the content of such activity of children's mastery of the socio-cultural experience. L.S. Vygotsky asserts that internal changes in a personality will be effective if the very process/result of the creation/ transformation of the amplificator is effective, and then will personality development take place. L.S. Vygotsky developed a theory showing how "through others, we become ourselves" and formulated an extremely important thesis that child development is directed not by the "force of things" but by the "connection of people". People are bound together by activity, in the depths of which relationships are formed.

These conceptual ideas allowed us to consider the positive socialization of 
a child as a motivated, purposeful, gradual, systematic mastery of sociocultural experience by a child on the vector of development amplification. Amplification is understood as an expansion (enrichment) of children's development through optimization of the content and means of education (Zaporozhets, 1986). Amplification implies gradual and consistent expansion of the circle of mastered objects and phenomena in a variety of their properties, functions, interrelations, therefore, it is based on apperception (Zaporozhets, 1986). Developing the conceptual ideas of A.V. Zaporozhets (1986), V.T. Kudriavtsev (1999) proposed to consider the process of amplification as adults' assistance in transforming a child's activity with the participation of adults into the independent activity of children themselves aimed at transformation (re-construction) of the mastered content. As a result, the activity itself (in the variety of its types and forms) transforms from "an instrument of pedagogical influence" into "an instrument of self-development and selfrealization" for a child themselves. The amplification here becomes the leading pedagogical line as it integrates the main trajectories of child development and the expansion of their socio-cultural experience as unique personalities in the socio-cultural educational environment.

To solve the complex of the indicated problems of socialization of children, it is necessary to conduct interdisciplinary research in the field of social, psychological and pedagogical support of children in difficult life situations, their families and teachers who work with such children in social and educational organizations.
Problem of Study

The research toolkit was formed considering the research purpose and included the following questions:

- Do you personally feel any support for the family and the child from the state?

- From what sources do you know about the state family policy?

- What types of assistance to a young family from the state do you consider the most necessary?

- Do you know about the existence of children's centers on the territory of your settlement?

- Does your child take part in the activities of children's centers?

- What services for children do you think children's centers should provide?

- Do you know about the activities of social workers dealing with children's socialization?

- On what family issues do you need additional knowledge?

- Have your children ever suffered from bullying by their peers?

\section{Methods}

\section{Research Model}

Theprojectwascarriedoutusing theoretical and empirical research methods. Theoretical methods included, theoretical analysis of philosophical and aesthetic, culturological, and psychological and 
pedagogical literature; the method of theoretical modeling; analysis of psychological and pedagogical documents.

Empirical methods included studying the practical application of traditional and innovative forms, methods, and techniques of socialization of children in difficult life situations through art, as well as conversations, targeted pedagogical observations, and structured face-to-face interviews.

\section{Data Collection Tools}

The developments created as a part of the study were tested in the course of experimental work at eight innovative sites. A monitoring study involving 89 organizations was conducted. The empirical base of the study was significantly expanded through creative and scientific and practical events including the All-Russian scientific and practical conference "The Potential of Art in Socialization of Children in Difficult Life Situations: Theory and Practice", the regional competition of students' monoperformances "Okrylenie" in the city of Smolensk, the scientific and practical cluster "The Potential of Art and Artistic Activity in Socialization of Children in Difficult Life Situations" in the city of Smolensk, the All-Russian scientific and practical cluster "Pedagogical potential of the art of clowning and street theater in the socialization of children and adolescents in difficult life situations", the All-Russian competition of pedagogical initiatives in the field of socialization of children in difficult life situations by means of art, and the All-Russian scientific and practical conference "Socialization of children in difficult life situations by means of art".
The concept is based on a combination of adaptation and activity and sociocultural approaches to the study of the problems of the formation of human society as an integral socio-cultural community (M.M. Bakhtin, L.S. Vygotsky, A.F. Losev, Iu. M. Lotman, etc.), the aesthetic theories of T.V. Adorno, V.V. Bychkov, cultural-historical psychology (L.S. Vygotsky, A.R. Luriia), the theory of socio-cultural stratification (A.la. Rubinstein, V.S. Zhidkov, K.B. Sokolov, la.U. Fokht-Babushkin, A.la. Gurevich), the ideas on artistic creativity developed by L.S. Vygotsky, A.V. Bakushinsky, B.P. Iusov, A.A. Melik-Pashaev, and others, the ideas of artistic pedagogy as a science of education and training in the works of H. Read, S. Gerasimov, B.M. Nemenskii, G.M. Tsypin. The methodological basis of the study also included conceptual provisions of the works of J. Habermas, E. Erikson, K. Jaspers, M. Weber, H. Marcuse, A. Maslow, T. Parsons, A. Toffler, A. Flier, P. Sorokin, and A. Toynbee. Analysis of ideas about socialization in different approaches (psychometric, psychoanalytic, psychosocial, hermeneutic, dialogic, cognitive, existential, ontological, axiological, cultural-historical, culturological, polyartistic, synergetic, integrative, situational, vector-contextual) allowed to substantiate the combination of dialogic (Bakhtin (1979), Mamardashvili (1990)), culturological (Krylova (2000), Kudryavtsev (1997)) and polyartistic (lusov (2004), Savenkova (2018)) approaches as the key condition of the effectiveness of a pedagogical model for the socialization of children in difficult life situations by means of art.

\section{Data collection procedure}

Data collection for the subsequent development of the concept of 
pedagogical support for the productive socialization of children was carried out based on a structured face-to-face interview.

Target group: parents of children aged 7 to 14 (Russian citizens).

Geography: 14 administrative units of the Smolensk region, the Russian Federation. Sample population: 1,000 respondents are presented in figure 1 . aged 30 to 45 years, representative of the main socio-demographic characteristics (gender, age, size of the settlement).

\section{Results}

According to the survey results, the share of parents who had a positive attitude to the current state support of the family and the child was $62.5 \%$. The results of the survey for the question "Do you personally feel any support for the family and the child from the state?"

\section{Do you personally feel any support for the family and the child from the state?}

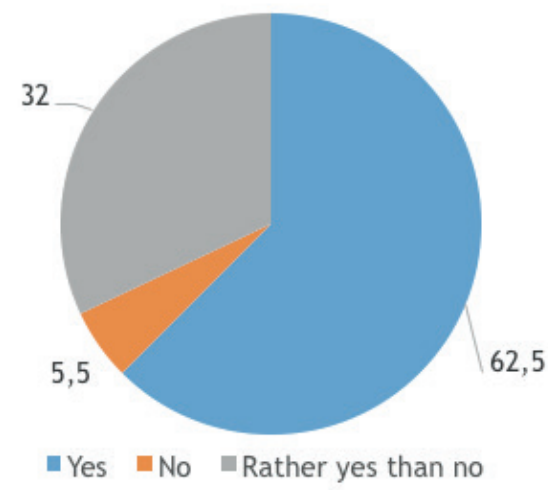

Figure 1. Attitude to the current state support of the family and the child

Distribution of answers to the questions existence of state family policy, the most "From what sources do you know about common source was the Internet (except the state family policy?" showed that for social networks). The distribution of for those parents who knew about the answers is presented in Figure 2.

From what sources do you know about the state family policy?
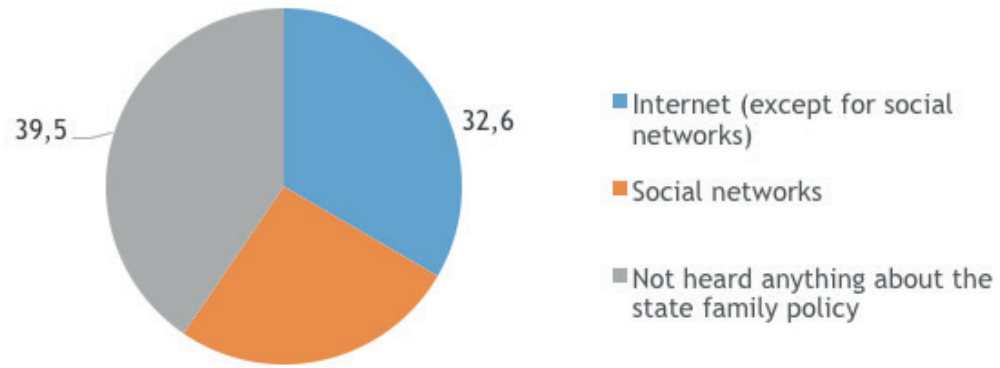

25,5

Figure 2. The existence of state family policy 
The increase in the size of the allowance for children was noted as the most necessary type of assistance to the family by half of the respondents $(50.9 \%)$. The second most frequently mentioned type of state aid by the respondents was the provision of cheap loans to families with children. Among types of assistance that families with children need from the state, every fourth respondent noted the help of a family psychologist and a reduction in the working day. The distribution of answers is presented in Figure 3.

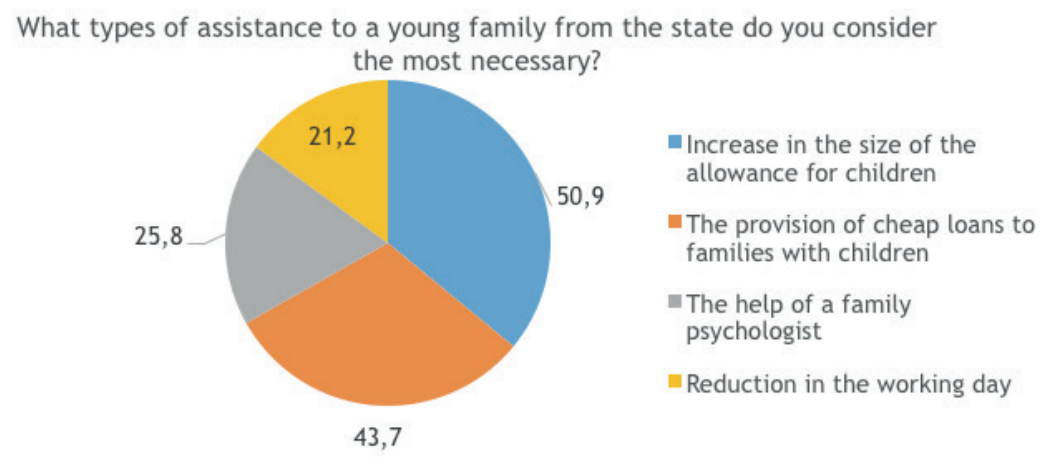

Figure 3. Types of assistance to a young family from the state

Answers to the question "Do you know about the existence of children's centers on the territory of your settlement?" showed that $48.5 \%$ of the respondents did not have information about the existence of children's centers on the territory of their settlements. Other noted the absence of children's centers in their communities. At the same time, some respondents noted that they knew about the existence of children's centers but their children did not attend them for various reasons. The results of the survey is presented in Figure 4.

\section{Do you know about the existence of children's centers on the territory of your settlement?}
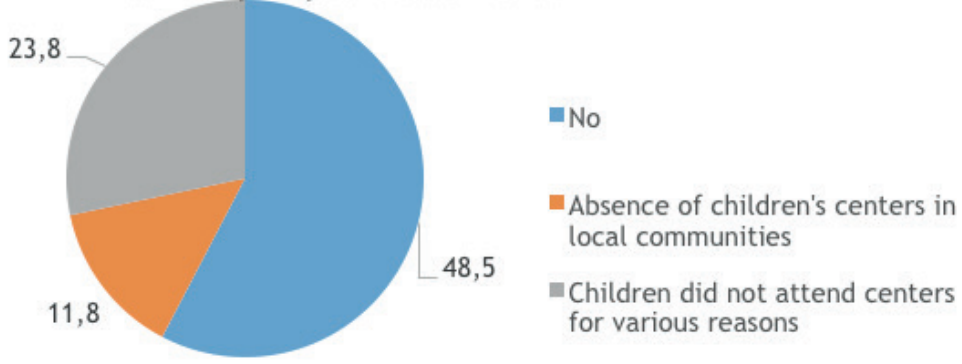

Figure 4. Respondents' answers about the existence of children's centers in settlement.

Answers to the question "Does your child take part in the activities of children's centers?" showed that for $12.4 \%$, children took or had taken part in the activities of children's centers. At the same time, $2.8 \%$ had children who were active participants in the activities of these centers.

According to the interviewed parents, children's centers as institutions whose activities are aimed at creating conditions 
for the development and socialization of children, as well as ensuring their meaningful and high-quality leisure, should provide services for club activities (51.9\%), including related to art (43.4\%), sports section services (51.3\%), work with crisis categories of children (45.0\%), and consultations with a child psychologist (44.2\%).

When asked about the activities of social workers involved with children, the respondents divided almost in half into those who did not know about them $(51.8 \%)$ and those who were more or less aware of them (41.7\%). Only $8.9 \%$ of parents turned to social workers for help, and $28.5 \%$ knew about social workers dealing with children but had not had a chance to contact them.

Almost half of the respondents (45.9\%) noted that there was no need to obtain additional knowledge on the issues of raising children. Among the main issues of raising children, on which there was a need to deepen knowledge, the respondents named overcoming childparent conflicts $(18.2 \%)$, the formation of partnerships between parents and children (13.1\%), and raising difficult children (13.0\%).

When answering the last question, $67.0 \%$ answered that their children had not suffered from bullying by peers in educational institutions. $17.0 \%$ found it difficult to answer the question. However, among the respondents, there was a high percentage $(16.0 \%)$ of people whose children, to a degree, had suffered from bullying by their peers in educational institutions, which is probably due to difficulties in socialization.
As a result of the conducted study, the Concept of pedagogical support for the productive socialization of children in difficult situations by means of art including a theoretical model for the organization of child socialization and integration in the socio-cultural space through active artistic and creative activity was developed.

The essence of the concept lies in substantiating the potential of art and art education in ensuring positive socialization of children in difficult life situations which is realized through their active involvement in artistic and creative activity. Pedagogical support for the process of socialization of children in difficult life situations that provides for their complete integration in social life and self-realization in various types of creative, social, and professional activity requires implementing a complex pedagogical system comprising the principles, conditions, content, technologies, and diagnostic instruments contributing to the development of an active life position of a child, their cultural and personal identity, and value attitudes corresponding to the traditional values of Russian culture. As a result of our research, we concluded that, pedagogical support of children's socialization using the means of art implies organizing a creative developmental environment in various educational and social institutions, as well as the system of additional education by applying the potential of theatrical, musical, visual, and literary activities. In short, the method of artistic creation or the artistic-creative method is a system of historically developed principles of artistic and figurative thinking in art contingent on the nature 
and level of development of society, the philosophical, social, scientific, religious, ethical, and aesthetic ideals prevalent in a given society, and also comprises the methods of artistic generalization, the principles of artistic selection, aesthetic criteria for evaluating the world accounting for the concept of beauty in the given time period, and the existing techniques of conveying artistic images. The method of artistic creation presupposes the activity of the creator expressing their thoughts, feelings, and experiences correlated with the artistic life of society and the art characteristic of a given era. The artistic and creative activity of a person forms based on this method.

\section{Discussion}

Based on our results, we consider it necessary to clarify that socialization is the result of a constantly unfolding process of human interaction with the surrounding world in all planes, it is integrated. Socialization is the process and result of the formation of the social qualities of the individual. Sociocultural experience forms based on the combination of all levels of the individual and the social in the process of a child's integration into culture and society. Therefore, the educational environment should be a flexible system of conditions of interaction between subjects of the pedagogical process that are specially organized in space and time and contribute to the development of a child's sociocultural experience accounting for their individual characteristics, as well as the educational needs of the family, society, and the state.

The development and approbation of the theoretical model "Support for the positive socialization of children in difficult life situations by means of art" based on the combination of the dialogical, culturological, and polyartistic approaches revealed the potential of different types of art and children's artistic creativity (literature, folk arts and crafts, artistic construction, puppet theater, shadow theater, floristics, etc.) in positive socialization of elementary school children in difficult life situations, as well as allowed to develop content for teachers and parents in the form of methodological recommendations.

Based on our results and research results [], we will try to generalize the methodological material we propose for working with children in difficult situations and classify them depending on their social and pedagogical characteristics.

In our research, child socialization is considered from the point of the development of cultural and creative initiative and motivation for social creativity in the context of designing socio-cultural programs. The organization of conditions for child socialization implies the diversity and saturation of lessons on culture and art and involving children in various artistic activities focusing on the type of artistic perception of the surrounding life and different life situations predominant at the given age (through action, image, literary text, music, poetry, theater, dance).

Components within the educational environment model are identified in their totality and interrelation: the activity, social, and object-spatial. The model of 
the educational environment is based on the "triangle of mediation" developed by Y. Engeström within the framework of the activity-based approach. The main goal of this approach is to unite the social and the public in human activity accounting for the problematic sphere of communication which is separated from and opposed to the instrumental and object aspects of activity by some researchers (Kozhevnikova, 2018, p. 76).

By pedagogical conditions of productive socialization of children in difficult life situations, we mean a process of preparation of various sociocultural programs involving students' interaction with works of art by means of an organized socio-cultural space, the development of cultural and creative initiative of each child, and encouraging their artistic and creative activity. The cultural and creative initiative is considered as an active manifestation of internal motivations that manifests in a new productive result and is associated with an individual's orientation on cultural values and social creativity. Children's social creativity is a socially significant activity of creating new products of activity in the interests of society and serves as a factor in achieving success and personal selfrealization. Pedagogical support of children's productive socialization by means of art involves using the potential of theatrical, musical, visual, literary activities, creating a creative developmental environment in various educational institutions, and the system of additional education.

In order to implement the individualpersonal approach in the implementation of the Concept, it is necessary to account for the characteristics of children, both psychological and physiological. For this purpose children should have an opportunity to engage in a variety of activities and choose the exact type of activity that best suits their individuality and helps to reveal their creative potential. In order to create and support motivation for creative activity, it is important to consider the degree to which the given activity is accessible to children considering their characteristics and abilities, and what results they are able to achieve in it. In this case, we emphasize not so much the artistic value of the results of creative activity but the possibility of children's creative selfexpression, getting positive emotions from the creative process itself. For example, for this, we propose to use a set of author's art techniques "Glinianyi Liap" ["Clay Blob"], "Zhivaia liniia” ["Living Line"], "Zhivoi natiurmort" ["Living Still Life"], "Konfetnyi kaktus" ["Candy Cactus"], "Rucheek i kamushek" ["Stream and Pebble"], "Solnyshko v okoshke" ["Sun in the Window"], "Tsvetnye ladoshki" ["Colored Palms"], etc. aimed at supporting the socialization of children of early childhood, preschool and primary school age in difficult life situations is proposed. Thus, the primary requirement for creative activities for children in difficult life situations is the possibility of adapting such activities to the needs and opportunities of each child.

Considering children and adolescents with disabilities, work with them can utilize methods integrating the principles of theater and carnival play and the technology of creating carnival masks allowing to change the view of oneself by activating self-irony, self-denial 
through laughter, and carnival worldview and master the skills of carnival and playful communication (Bonkalo et al., 2021). The contingent of children and adolescents with disabilities requires theatrical techniques that integrate the art of clowning, musical eccentricity, and contemporary theater art (performance art) that focus on the mechanisms of playful self-distancing - the techniques of laughter and humor.

Carnival play and technologies of theater-performance are proposed as methods that can be used for the development of teenagers' selfreflection expressed through an autoreferential art statement. For the purpose of productive socialization, it is possible to use the techniques and means of psychological theater, clowning technology, performative forms of theater, methods of playback theater, elements of interactive theater, immersive theater, the "performancelecture" technology, lectures with elements of performance art, forms of inclusive theater, transdramatic therapy techniques, the means of carnival speech communication genres, immersion in the life and communication of informal subcultural communities, carnival play activities, theater school exercises, circus eccentricity techniques, and film eccentricity. Publicly reading autobiographical stories provides an opportunity to look at oneself from an outside viewpoint. The socialization of children and adolescents using theatrical technologies allows solving the problems of formation of outlook positions and values; it promotes integration, social adaptation, and the acquisition of experience of participating in socially significant projects.
Using the potential of music that creates conditions necessary for the formation of basic musical culture and the development of cognitive and personal spheres of a person is an effective instrument for the development of a person's emotional and volitional sphere, as well as their creative abilities. For instance, a person deprived of sight is in a difficult life situation being unable to see the world. In the absence of vision, not only cognitive processes but also perception, imagination, visual and figurative thinking suffer, there are changes in the development of motor functions, and the acquisition of social experience is limited. Auditory perception is of particular importance for the blind and visually impaired. Musical art perceived through hearing conveys impressions of the surrounding reality that are inaccessible through the visual perception of social life. The universality of musical art lies in its ability to not only develop, educate, and spiritually enrich but also successfully rehabilitate children and adolescents with visual impairments. Scientific studies disclosing the mechanisms of the impact of music on a person (sound is an acoustic signal that has a wave nature) indicate several parameters: the electromagnetic conductivity of cellular structures, as well as their electrochemical activity, auditory receptivity, and vibrotactile receptivity. The first parameter indicates the response of the human body to musical and sound effects. The second one implies that music is perceived through the auditory system and the sounds that carry certain information. The third parameter indicates the work of the tactile analyzer in the perception of the vibration initiated by the musical influence. Musical factors - tempo, 
rhythm, and the structure of a piece can subordinate the rhythm of internal physiological processes. The impact of music on the human body, as well as music and pedagogical practices, contribute to the rehabilitation of people with disabilities throughout all stages of learning and education. With the transition to each new level of musical education - from early childhood to adolescence - the arsenal of musical activities - listening to music, singing, musical and rhythmic movements, plastic intonation, playing musical instruments, musical games, improvisation - contribute to the productive socialization of an individual.

Among the methods that can be used we can list the "Musical dialogue method" cooperative music-making improvisation of the teacher and the student with musical circumstances they offer to each other (different genre intonation complexes); the "Verbal visualization" method" - a verbal exploration of a phenomenon that would motivate the composing (music-making) student to "explore it through sounds"; the "Synesthesia method" - recalling and discovering the concepts and phenomena that have nothing to do with music at first glance but may initiate musical and figurative clarification (for example, "bitter harmony", "aromatic intonation") that can serve as an additional mechanism for remembering the specifics of the discovered technique, intonation, chord, etc.

The basis of the organization of the process of socialization of children in difficult life situations is formed by the principles of: 1) artistic self-education; 2) self-esteem and self-development; 3 ) artistic communication; and 4) creative self-identification.

1. The principle of artistic selfeducation. Artistic self-education is considered as an independent, voluntary, and purposeful process of personal development aimed at the acquisition of new artistic and aesthetic experiences and the development of artistic communications. The term "artistic self-education" is disclosed in scientific works through the prerogative of manifestation of artistic consciousness, the manifestation of the internal and external activity of an aesthetic nature, the freedom of creativity and self-creation allowing to create and integrate the goals, ways, conditions of one's development independently and creatively, orientation on the "creation of principally new results in which individual features of the subject manifest" (Zinchenko, 2010, p. 226).

The primary type of needs in the process of artistic self-education is the personally-oriented and value and meaning needs. This is the reason why the stimulation of artistic consciousness and initiative in the form of providing independence and freedom of action is so important. Artistic self-education takes place on three levels: free and versatile development of one's personality based on the attitude towards culture as the most important condition for such development; communication with works of art based on their adequate aesthetic evaluation and the need for such communication; independent artistic activity, the need to carry out this activity as a vital necessity.

2. The principle of self-esteem and self- 
development. Self-esteem occupies an important place among personality characteristics as it is one of the key components of a person's "Self" (Burns, Dobson, 1984). Self-esteem is the starting point for a person to "look at" themselves "from an outside perspective" when assessing themselves, their capabilities, qualities, and place among other people. It influences the effectiveness of activity, behavior, and further personality development as it is associated with a person's level of pretensions - the difficulty of the goals they set for themselves. The most consistent and complete manifestation of self-esteem is an individual's aesthetic consciousness that, along with its "aesthetic" function, also performs the task of creating a personal plan of perception, evaluation, creation of meanings and forecasts, setting behavior objectives, predicting the results of actions. Thus, aesthetic consciousness determines personal orientations, especially aesthetic and creative orientations in various life situations including crisis situations (lonin, 2004).

Self-development is the ability to change oneself and one's life according to one's needs and desires, one's own choice. However, we consider self-development to be present only when a person purposefully and consciously searches for a way out of a crisis situation while their attitude towards the world around them, themselves, and other people changes significantly, when personal changes take place, the ways of activity transform, and new norms and relations created by a person themselves appear.

3. Theprincipleof artisticcommunication. The concept of "communication" (from
Latin communico - message, transfer) can be defined as the exchange of thoughts, information, ideas, communication, etc.; the transfer of information from one consciousness (collective or individual) to another by means of signs and symbols recorded on any media. The problem of "communication" was most extensively developed within the framework of the science of science where such forms of communication as publication, discussion, intellectual influence, etc., have been quantitatively and qualitatively investigated. In modern scientific research, artistic communication is viewed as a complex system in which the appropriation of artistic and cultural values, the formation of artistic needs, interests, and creative development of the individual take place. In a broad sense, artistic communications include the whole variety of information processes concerning works of art, authors, their cultural and historical fate, the attitude of society towards them, etc. Communicative possibilities of art language are explored in the works of M.M. Bakhtin, V.S. Bibrer, L.S. Vygotsky, B.S. Mailakh, S.H. Rappoport, L.N. Stolovich, B.P. lusov and others and considered from the point of relationships: between the viewer and the author of the work, the viewer and the era of work creation, the viewer and other spectators in the context of universal unity. In scientific research, art communication is primarily understood as a mechanism of cognition of the information "encoded" by the author in the work of art.

4. The principle of creative selfidentification. The striving for creative activity, for the search for something new, is a natural property of a self- 
developing personality. The works of D.A. Leontiev show that since the need for activity differs from the need for objects it is necessary to interpret it not only as a person's "request" to the objective world but also as a demand of a certain productive activity (creation) from themselves. Among the methods used for the development of children's creative self-determination, we should note the subject, thematic, or other integration (interaction) of academic subjects. B.P. lusov (2004) noted that when carrying out such integration, it is necessary to account for the geographical, historical, and cultural factors influencing the creation of products of artistic and creative activity in a single cultural stream, as well as to consider the present or establishing connections between art and sciences in the context of the creative manifestation of humanity in which people feed off each other's achievements and combine into a unified whole. B.P. lusov especially emphasized the variety of interaction and mutual interaction of academic subjects: 1) within a single subject (integration of concepts, knowledge, skills); 2) between two or more different academic subjects (connection of concepts, principles, terms, events); 3) the connection of practice and theory of basic and supplementary education which the author designated as transdisciplinary. In order to take part in such an integrated process, an individual must take the initiative and be able to "get" the necessary information on their own (lusov, 2004).

The main requirements for the socialization of children in difficult life situations are: 1) consideration and demand for pedagogical efforts of teachers of different academic disciplines (geography, history, literature, music, fine arts, etc.) in the development of tasks for the creation of regional cultural and educational roadmaps; 2) support for creative motivation as a dominant in the transition to the zones of the nearest creative development and selfdevelopment of students in the conditions of studying a certain region of Russia; 3 ) the creation of an additional open virtual educational space contributing to the cognitive, emotional and emotional and active development of an individual; 4) the implementation of purposeful management of the process of creating individual socio-cultural programs.

\section{Conclusion}

The Concept of pedagogical support for the productive socialization of children in difficult situations by means of art including a theoretical model for the organization of children's socialization and integration into the sociocultural space through active artistic and creative and musical activity is developed. The principles of aesthetic education and art education for children in difficult situations are substantiated.

The authors show that the assessment of the impact of various types of art and creative activities on the level of productive socialization of children in difficult life situations correlates with the obtained data on the interest in these types of creativity. The pedagogical potential of means of art and artistic and creative and musical activity in the socialization of children is revealed.

\section{Acknowledgement}

The article was written within the framework of the State assignment 
of the Ministry of Education of the Russian Federation for the Federal State Budgetary Scientific Institution "Institute of Art Education and Cultural Studies of the Russian Academy of Education" No. 073-00026-20-01 on the project "Socialization of children in difficult life situations by means of art" No. AAAA-A20-120030590088-6 for 2020. 


\section{Biodata of Authors}

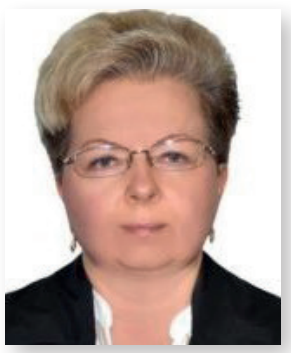

Irina Vladimirovna Wagner, Dr.

Interest of author: problems of the ecology of childhood, the development of the ecological culture of the individual, ecological ethics, ecological education and upbringing Affiliation: Institute of Art Education and Cultural Studies of the Russian Academy of Education, Moscow, Russia e-Mmail: Wagner.I.V@yandex.ru

ORCID: https://orcid.org/0000-0003-3932-1736 Elibrary: https:// elibrary.ru/author_profile.asp?authorid=614729\&

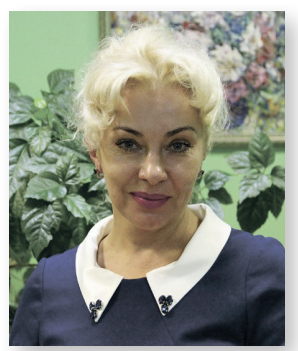

Ekaterina Mikhaylovna Akishina, Dr.

Interest of author: pedagogy, modern music education, cultural development of a child in modern society Affiliation: Institute of Art Education and Cultural Studies of the Russian Academy of Education, Moscow, Russia e-Mail: ekaterina.m.akishina@mail.ru ORCID: https: / / orcid.org/0000-0002-1345-5202 Elibrary: https://elibrary.ru/author_ profile . asp?authorid $=256310$

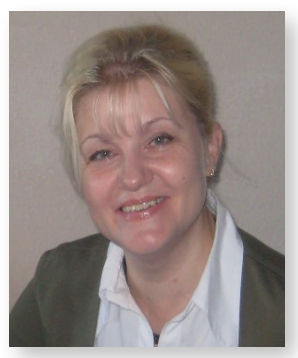

\section{Elena Petrovna Olesina, $\mathrm{PhD}(\mathrm{c})$}

Interest of author: pedagogical technologies, art in education, socialization of schoolchildren Affiliation: Institute of Art Education and Cultural Studies of the Russian Academy of Education, Moscow, Russia e-Mail: olesina611076@mail.ru ORCID: https: / /orcid.org/00000002-3703-0356 Elibrary: https://elibrary.ru/author_profile.asp?auth orid $=400070$ 


\section{References}

Aleksandrova, I.B., Vorobyova, K.I., Gileva, N.V., Livson, M., Cheprasova, T.V., Bazhin, G.M. (2021). Influence of Digital Assistive Technologies Used in Higher Education on the Development of Individual Educational Strategies among Students with Disabilities. International Journal of Early Childhood Special Education, 13(2), 1146-1153. http://doi. org/10.9756/INT-JECSE/V13I2.211160.

Bakhtin, M.M. (1979). Aesthetics of verbal creativity. Moscow: Iskusstvo.

Bogush, A., Kovshar, O., Kovtun, 0. Bulgakova, O. (2021). Pedagogical Conditions for The Formation of Professional Culture of Future Educators of Preschool Educational Institutions. Propósitos y Representaciones, 8 (SPE2), e676. http://dx.doi.org/10.20511/ pyr2020.v8nSPE2.676

Bonkalo, T.I., Shmeleva, S.V., Nazarenko, V.V., Karpov, V.Y., Logachev, N.V., Kumancova, E.S. (2021). Activating Model of Professional Training of Persons With Disabilities as Competitive Specialists In Higher Education Establishment. Laplage Em Revista, 7(3A), 235-244. https: / / doi.org/10.24115/S24466220202173A1396p.235-244

Burns R.B., Dobson C.B. (1984) The selfconcept. In: Introductory Psychology. Springer, Dordrecht. https://doi. org/10.1007/978-94-011-6279-1_13

Dewey, J. (1915). Froebel's educational principles. In: The school and society by J. Dewey (pp. 111-127). Chicago: University of Chicago.
Ionin, L.G. (2004). Sotsiologiia kultury: Uchebnoe posobie dlia vuzov [Sociology of culture: Textbook for universities]. Moscow: Higher School of Economics Publishing House.

lusov, B.P. (2004). Vzaimosviaz kulturogennykh faktorov $v$ formirovanii sovremennogo khudozhestvennogo myshleniia uchitelia obrazovatelnoi oblasti "Iskusstvo": izbr. tr. po istorii, teorii i psikhologii khudozhestv. vospitaniia detei [The relationship of cultural factors in the formation of modern artistic thinking of teachers in the educational field "Art": selected works on the history, theory, and psychology of artistic upbringing of children]. Moscow: Sputnik+, 252 p.

Kozhevnikova, V.V. (2018). Modelirovanie obrazovatelnoi sredy dlia detei rannego vozrasta na osnove amplifikatsii razvitiia [Designing the educational environment for young children based on developmental amplification]. Ph.D. dissertation in pedagogical sciences. Institute for the Study of Childhood, Family and Education of the Russian Academy of Education, Moscow, Russia.

Krylova, N.B. (2000). Cultural education. Moscow: Education.

Krylova, N.B. (2007). Razvitie kulturologicheskogo podkhoda $\mathrm{v}$ sovremennoi pedagogike [Development of the culturological approach in modern pedagogy]. In: I.M. Bykhovskaya (Ed.), Lichnost $v$ sotsiokulturnom izmerenii: istoriia i sovremennost: a collection of articles (pp. 132-138). Moscow: Indrik.

Kudriavtsev, V.T. (1999). Psikhologiia razvitiia cheloveka: osnovaniia kulturno- 
istoricheskogo podkhoda [Psychology of human development: the foundations of the cultural and historical approach]. Moscow: "Eksperiment" publishing house.

Kudryavtsev, V.T., Urazalieva, G.K. (1997). Creative dominant culture, In: Problems of integration of science and human knowledge in the theory of activity and motor actions. Nizhny Novgorod: NSPU.

Mamardashvili, M. K. (1990). Consciousness is a paradox, which is impossible to get used to, In: As I understand philosophy. Moscow: Progress.

Savenkova, L.G. (2018). The polyartistic in education, or "when all arts are combined", Art education in Russia at the present stage: scientific search, updating the content and improving the quality. Moscow: Federal State Research Institution of the Russian Academy of Education "Institute of Art Education".

Shatskaya, I. (2021). Assessment of the quality of the educational process for students with disabilities. Apuntes Universitarios, 11(4), 548-559. https:// doi.org/10.17162/au.v11i4.856

Slobodchikov, V.I. (2005). Ocherki psikhologii obrazovaniia [Essays on the psychology of education] (2nd ed., revised and enlarged). Birobidzhan: Birobidzhan State Pedagogical Institute Publishing House.

Vygotsky, L.S. (1983). Sobranie sochinenii v $6 \mathrm{t}$. [Collected Works in 6 volumes]. Vol. 3. Moscow: Pedagogics.
Zaporozhets, A.V. (1986). Izbrannye psikhologicheskie trudy: $v 2 \mathrm{t}$. [Selected psychological works: in 2 volumes]. Moscow: Pedagogics.

Zinchenko, V.P. (2010). Soznanie i tvorcheskii akt: Monografiia [Consciousness and creative act: Monograph]. Moscow: Languages of Slavic cultures.

Zinchenko, V.P., Morgunov, E.B. (1994). Chelovek razvivaiushchiisia. Ocherki rossiiskoi psikhologii [Developing person. Essays on Russian psychology]. Moscow: Trivola. 
